\title{
COMPARISON OF OXIDATION STABILITY OF VIRGIN OLIVE OILS FROM DIFFERENT LOCATIONS OF TURKEY
}

\author{
M. Karakuş ${ }^{\mathrm{a}}$, A. BayraK ${ }^{\mathrm{b}}$, E. ÇALIKoĞLU ${ }^{\mathrm{c}}$ and M. Kiralan ${ }^{\mathrm{d} *}$ \\ a Türk Telekom, 06103 Ankara. Turkey \\ ${ }^{\mathrm{b}}$ Food Engineering Department, Engineering Faculty, Ankara University, 06110 Ankara. Turkey \\ ${ }^{\mathrm{c}}$ General Directorate of Agricultural Research and Policy, \\ Ministry of Food, Agriculture and Livestock, Republic of Turkey, 06060 Ankara. Turkey \\ ${ }^{\mathrm{d}}$ Food Engineering Department, Abant Izzet Baysal University, 14280 Bolu. Turkey
}

(Received: 24 July 2012; accepted: 23 October 2012)

Ten kinds of virgin olive oil of two major cultivars (Ayvalık and Memecik) produced in several areas of Turkey (Bayındır, Edremit, Ortaklar, Burhaniye, Ezine, Tire, Havran, Ayvalık, Altınoluk, and Küçükkuyu) were analysed. The quality characteristics, fatty acid composition, total phenol, and $o$-diphenol content of the samples were determined. Oxidative stability and free radical scavenging activity were determined using Rancimat test, Schaal oven test, and DPPH method. It was found that while Memecik oil from Ortaklar demonstrated the strongest oxidative stability, Ayvalık oil from Ezine had the lowest oxidative stability among the samples. Fatty acid composition and especially oleic acid/linoleic acid ratio was previously defined as a parameter that can help distinguish cultivars from one another; however, this study proved that total phenol, especially $o$-diphenol content of the oil, has the strongest effect on oxidative stability compared to other factors including fatty acid composition.

Keywords: virgin olive oil, Memecik, Ayvalık, location, oxidative stability, Schaal oven, Rancimat, DPPH

Turkey is an important olive and olive oil producer and exporter country. According to IOC data in 2008/2009 harvest period, Turkey produced 300000 tons of table olives and 130000 tons of olive oil (ANON., 2009). Several olive cultivars exist in Turkey and these cultivars are processed for table olive and olive oil production. Major olive cultivars for oil production are Memecik and Ayvalık olive cultivars. They are widely grown in Aegean and Marmara regions of Turkey.

Muğla province is the origin of Memecik cultivar. It is also called Asiyeli, Gülümbe, Milas, Sehir, Taşarası, Tekir, Yağlık, Yağlık sarı zeytin, and Yağlık çelebi. This cultivar is produced for oil (15\%), table (30\%), and double-purpose (53\%) (ANON., 2008).

Ayvalık cultivar's origin is Edremit in Marmara region. It is also named as Ada zeytini, Alaca, Midilli, Edremit yağlık, and Sakran. This cultivar is produced for oil (76\%), table (15\%), and double-purpose (7\%) (ANON., 2008).

The main components of virgin olive oil are triacylglycerols and unsaturated fatty acids, which are susceptible to autoxidation. Most of the beneficial compounds in olive oil, such as tocopherols, sterols, and phenols, etc., are preserved since virgin olive oil is not refined and these are the compounds which contribute to the strong antioxidant activity, flavour, and colour, unique to virgin olive oil (Kiritsakis, 1998; Velasco \& Dobarganes, 2002). The antioxidant content of oil is not constant; it depends on the cultivar, locations, olive growing techniques, processing, and storage, etc. (BELTRÁn et al., 2005). Oxidative stability, one of the most important quality marker of edible oils, is commonly evaluated by accelerated methods

\footnotetext{
* To whom correspondence should be addressed.

Phone: +90 374-2534640; fax: +90 374-2534558; e-mail: mustafakiralan@yahoo.com
} 
employing relatively high temperatures and air flow supply (e.g., Rancimat, active oxygen method, and oxidative stability instrument) (BALDIOLI et al., 1996; ApARICIO et al., 1997).

In this study, oxidation stability of ten oil samples from several important olive oil production locations in Turkey is analysed. The quality characteristics, fatty acid compositions, total phenol and $o$-diphenol contents of samples were determined. Oxidation stability and free radical scavenging activity were determined by using Rancimat test, Schaal oven test and DPPH method. Moreover, relations between total phenol, o-diphenol, Rancimat, Schaal oven test and DPPH method were discussed.

\section{Materials and methods}

\subsection{Materials}

Oil samples of 10 different kinds of olives from Ayvalık and Memecik cultivars which were produced at different locations (Table 1) in Turkey, were provided by Taris Unions of Agricultural Co-Operatives. All were processed with the same method during the 2007-2008 harvest period.

\subsection{Methods}

Peroxide value (PV), free fatty acid (FFA), and UV absorption characteristics $\left(\mathrm{K}_{232}, \mathrm{~K}_{270}, \Delta \mathrm{K}\right)$ were determined by the $\mathrm{Cd} 8-53, \mathrm{Ca} 5 \mathrm{a}-40$, and $\mathrm{Ch}$ 5-91 methods described in the American Oil Chemist's Society, respectively (A.O.C.S, 1997a; 1997b; 2005).

Fatty acids were converted to their methyl esters (IUPAC, 1987) and injected into a Shimadzu GC-2010 model (Kyoto, Japan) gas chromatograph, fitted with a FID detector. Separations were performed using a TR-CN100 capillary column $(60 \mathrm{~m}, 0.25 \mathrm{~mm}$ i.d., 0.20 $\mu \mathrm{m}$ film thickness) (Teknokroma, Spain). Helium was used as carrier gas at a flow rate of $0.80 \mathrm{ml} \mathrm{min}{ }^{-1}$. Injector and detector temperatures were 230 and $240{ }^{\circ} \mathrm{C}$, respectively. Column temperature was kept at $185^{\circ} \mathrm{C}$ for $40 \mathrm{~min}$. Samples of $1 \mu \mathrm{l}$ were injected with the use of an auto-injector in split mode (1:50). FAMEs were identified by comparison of their retention times with those of the reference standards.

Phenols were extracted following the method proposed by KALANTZAKIS and co-workers (2006). Five grams of olive oil were dissolved in $10 \mathrm{ml} n$-hexane to remove oil and extracted with $10 \mathrm{ml}$ of a methanol water mixture $(60: 40, \mathrm{v} / \mathrm{v})$, then shaked vigorously by means of a vortex, and centrifuged at 3500 r.p.m. for $10 \mathrm{~min}$.

The total phenol content (TPC) of the extracts from the used method (KALANTZAKIS et al., 2006) was determined using Folin-Ciocalteu reaction. Two hundred microliters of phenol extract was diluted with water to a total volume of $5 \mathrm{ml}$, followed by the addition of $0.5 \mathrm{ml}$ Folin-Ciocalteu reagent. After $3 \mathrm{~min}, 1.0 \mathrm{ml}$ of sodium carbonate solution $(35 \%$, w/v) was added, mixed, and diluted with water to $10 \mathrm{ml}$. The mixture was allowed to stand for 1 $\mathrm{h}$. The absorbance of the solution was measured after $1 \mathrm{~h}$ against a blank sample using UVVIS spectrophotometer at $725 \mathrm{~nm}$. The results were expressed in $\mathrm{mg}$ caffeic acid/kg oil.

$o$-Diphenol concentrations were determined in a $4 \mathrm{ml}$ sample of each phenolic extract taken from the previously mentioned procedure (KALANTZAKIS et al., 2006). These samples were added to $1 \mathrm{ml}$ of a $5 \%$ solution of sodium molybdate dihydrate in ethanol/water $(1: 1$, $\mathrm{v} / \mathrm{v}$ ) and were shaken vigorously. After $15 \mathrm{~min}$, the absorbance at $370 \mathrm{~nm}$ was measured using caffeic acid for the calibration curve. The results were expressed as $\mathrm{mg}$ caffeic acid $/ \mathrm{kg}$ oil (CERRETANi et al., 2005). 
Oxidation stability index (OSI) values were examined using the Rancimat equipment (Metrohm Ltd., Herisau, Swiss) at $120{ }^{\circ} \mathrm{C}$ with a continuous air flow of $201 \mathrm{~h}^{-1}$ passing through the oil samples. The inflection point of the curve was assigned as the induction time and given in hours (WAGNER \& ElMADFA, 2000; KoprivNJAK et al., 2008).

The free radical scavenging activity was measured by DPPH (2,2-diphenyl-1picrylhydrazyl) method in total olive oil samples and in methanol:water extracts from oil samples. The following method was used to determine free radical scavenging activity of methanol/water extract. The extract solution $(0.5 \mathrm{ml})$ was added to $3 \mathrm{ml}$ of a $10^{-4} \mathrm{M}$ methanolic solution of DPPH and vortex-mixed. After $20 \mathrm{~min}$ of incubation, the absorbance was measured at $515 \mathrm{~nm}$ (KALANTZAKIS et al., 2006) and free radical scavenging action toward DPPH radical was estimated from the difference in absorbance with or without sample (control) and the percent of inhibition was calculated with the following equation:

$$
\text { Inhibition } \%=\frac{\mathrm{A}_{\text {control }}-\mathrm{A}_{\text {sample }}}{\mathrm{A}_{\text {control }}} \times 100
$$

The free radical scavenging activities in total olive oil samples were determined according to a reported procedure (KALANTZAKIS et al., 2006). One $\mathrm{ml}$ of oil solution (10\% w/v) was added to $4 \mathrm{ml}$ of a freshly prepared DPPH solution $(0.1 \mathrm{mM})$ in a $20 \mathrm{ml}$ test tube, which was immediately tapped and vigorously mixed for $10 \mathrm{~s}$ using a vortex apparatus. Ethyl acetate was used as a solvent. Absorbance of the mixture was measured for $30 \mathrm{~min}$ at $515 \mathrm{~nm}$ and the percent of inhibition was calculated according to the above-mentioned formula.

Schaal oven test was carried out in dark for 30 days at $60{ }^{\circ} \mathrm{C}$ in an oven with active air circulation. During storage, samples were withdrawn for analysis and the progress of oxidation was followed by $\mathrm{PV}, \mathrm{K}_{232}$, and $\mathrm{K}_{270}$ as mentioned above. A Hitachi U-2800A UV/ VIS spectrophotometer (Tokyo, Japan) was used for spectrophotometric measurements.

\subsection{Statistical analysis}

Statistical analysis was carried out using SPSS 11.5 (2002) software. One-way ANOVA followed by "Duncan's test" was applied to calculate the difference (at 95\% level) between mean values of some basic quality parameters of olive oil samples. Same statistical analysis was applied to mean values of three of these parameters $\left(\mathrm{PV}, \mathrm{K}_{232}\right.$, and $\mathrm{K}_{270}$ ) during Schaal Oven test. The Pearson correlation test was used to determine correlations between total phenol, $o$-diphenol, RSA, OSI, PV, and oleic acid/linoleic acid ratio (C18:1/C18:2). Ten olive oil samples from two cultivars were analysed with two replications.

\section{Results and discussion}

Ten olive oil samples from two cultivars (Ayvalık and Memecik) and different locations in Aegean and Marmara Regions are shown in Table 1.

The quality characteristics (FFA, $\mathrm{K}_{232}, \mathrm{~K}_{270}$, and $\Delta \mathrm{K}$ values) of oil samples are presented in Table 2. FFA and PV contents vary between $0.68-0.80 \%$ and $7.24-15.83 \mathrm{meq} \mathrm{O} / \mathrm{kg}$ oil, respectively. $\mathrm{K}_{232}, \mathrm{~K}_{270}$, and $\Delta \mathrm{K}$ values were between $1.22-2.36,0.06-0.21$, and $(-0.0022)$ (0.0036), respectively. The obtained results were below the limit values (FFA $0.80 \%$, PV 20 
meq $\mathrm{O}_{2} \mathrm{~kg}^{-1}$ oil, $\mathrm{K}_{232} 2.50, \mathrm{~K}_{270} 0.22$, and $\Delta \mathrm{K} 0.01$ ) for virgin olive oil established by the International Olive Oil Council's (IOOC) trade standard for olive oil and olive-pomace oil (ANON., 2006). FFA value reached the limit value $0.8 \%$ in only one sample.

Table 1. Areas and cultivars of olive oil samples obtained

\begin{tabular}{lll}
\hline Sample & Location & Cultivars \\
\hline T1 & Bayındır & Memecik \\
T2 & Edremit & Ayvalık \\
T3 & Ortaklar & Memecik \\
T4 & Burhaniye & Ayvalık \\
T5 & Ezine & Ayvalık \\
T6 & Tire & Memecik \\
T7 & Havran & Ayvalık \\
T8 & Ayvalık & Ayvalık \\
T9 & Altınoluk & Ayvalık \\
T10 & Küçükkuyu & Ayvalık \\
\hline
\end{tabular}

Table 2. Some quality parameters of olive oil samples

\begin{tabular}{lccccc}
\hline Samples & $\begin{array}{c}\text { FFA } \\
\text { (\%, oleic acid })\end{array}$ & $\begin{array}{c}\mathrm{PV} \\
\left(\mathrm{meq} \mathrm{O}_{2} \mathrm{~kg}^{-1} \text { oil }\right)\end{array}$ & $\mathrm{K}_{232}$ & $\mathrm{~K}_{270}$ & $\Delta \mathrm{K}$ \\
\hline T1 & $0.80 \pm 0.04^{\mathrm{a}^{\mathrm{a}}}$ & $13.86 \pm 0.80^{\mathrm{b}}$ & $2.18 \pm 0.08^{\mathrm{b}}$ & $0.12 \pm 0.00^{\mathrm{b}}$ & $0.0018 \pm 0.00^{\mathrm{c}}$ \\
T2 & $0.76 \pm 0.01^{\mathrm{ab}}$ & $15.05 \pm 0.57^{\mathrm{ab}}$ & $2.14 \pm 0.02^{\mathrm{b}}$ & $0.06 \pm 0.00^{\mathrm{g}}$ & $0.0033 \pm 0.00^{\mathrm{b}}$ \\
T3 & $0.71 \pm 0.01^{\mathrm{cd}}$ & $15.83 \pm 0.65^{\mathrm{a}}$ & $2.11 \pm 0.01^{\mathrm{b}}$ & $0.21 \pm 0.01^{\mathrm{a}}$ & $0.0036 \pm 0.00^{\mathrm{a}}$ \\
T4 & $0.72 \pm 0.01^{\mathrm{cd}}$ & $10.80 \pm 0.54^{\mathrm{c}}$ & $2.36 \pm 0.01^{\mathrm{a}}$ & $0.11 \pm 0.01^{\mathrm{de}}$ & $-0.0016 \pm 0.00^{\mathrm{g}}$ \\
T5 & $0.77 \pm 0.02^{\mathrm{ab}}$ & $12.05 \pm 0.70^{\mathrm{c}}$ & $2.18 \pm 0.01^{\mathrm{b}}$ & $0.10 \pm 0.00^{\mathrm{def}}$ & $-0.0013 \pm 0.00^{\mathrm{f}}$ \\
T6 & $0.71 \pm 0.02^{\mathrm{cd}}$ & $12.09 \pm 0.80^{\mathrm{c}}$ & $1.96 \pm 0.03^{\mathrm{c}}$ & $0.10 \pm 0.01^{\mathrm{ef}}$ & $0.0002 \pm 0.00^{\mathrm{d}}$ \\
T7 & $0.79 \pm 0.01^{\mathrm{b}}$ & $8.65 \pm 0.07^{\mathrm{d}}$ & $2.17 \pm 0.01^{\mathrm{b}}$ & $0.11 \pm 0.00^{\mathrm{bcd}}$ & $0.0003 \pm 0.00^{\mathrm{d}}$ \\
T8 & $0.73 \pm 0.00^{\mathrm{bc}}$ & $7.24 \pm 0.66^{\mathrm{e}}$ & $1.22 \pm 0.01^{\mathrm{e}}$ & $0.11 \pm 0.00^{\mathrm{bcd}}$ & $-0.0021 \pm 0.00^{\mathrm{h}}$ \\
T9 & $0.69 \pm 0.00^{\mathrm{cd}}$ & $7.77 \pm 0.09^{\mathrm{de}}$ & $1.43 \pm 0.03^{\mathrm{d}}$ & $0.12 \pm 0.01^{\mathrm{bc}}$ & $-0.0022 \pm 0.00^{\mathrm{h}}$ \\
T10 & $0.68 \pm 0.02^{\mathrm{cd}}$ & $11.57 \pm 0.13^{\mathrm{c}}$ & $1.91 \pm 0.01^{\mathrm{c}}$ & $0.09 \pm 0.00^{\mathrm{f}}$ & $-0.0005 \pm 0.00^{\mathrm{e}}$ \\
\hline
\end{tabular}

*Values are means \pm SD of two measurements. Means within a column with different letters are significantly different $(\mathrm{P}<0.05)$ by one-way ANOVA analysis.

The percentages of all fatty acids were also within the limits of the above-mentioned standard (Table 3). The analysis of fatty acid content demonstrated that oleic acid value was higher in Memecik cultivar compared to Ayvalık cultivar while the linoleic acid value was lower. As a result C18:1/C18:2 ratio is significantly higher in Memecik cultivar. It is known that this oleic to linoleic ratio is useful in the characterization of olive cultivars (APARICIO et al., 1999). 
Table 3. Fatty acid (\%) composition of olive oil samples ${ }^{\mathrm{a}}$

\begin{tabular}{lrrrrrrrrrr}
\hline & \multicolumn{1}{c}{ T1 } & \multicolumn{1}{c}{ T2 } & \multicolumn{1}{c}{ T3 } & \multicolumn{1}{c}{ T4 } & \multicolumn{1}{c}{ T5 } & \multicolumn{1}{c}{ T6 } & \multicolumn{1}{c}{ T7 } & \multicolumn{1}{c}{ T8 } & \multicolumn{1}{c}{ T9 } & T10 \\
\hline C14:0 & 0.01 & 0.01 & 0.01 & 0.01 & 0.01 & 0.01 & 0.01 & 0.01 & 0.01 & 0.01 \\
C16:0 & 12.27 & 12.50 & 12.55 & 12.93 & 12.41 & 11.61 & 12.02 & 13.09 & 11.64 & 11.77 \\
C16:1 & 0.85 & 0.81 & 0.88 & 0.78 & 0.81 & 0.84 & 0.99 & 0.95 & 0.99 & 1.08 \\
C17:0 & 0.06 & 0.09 & 0.05 & 0.16 & 0.17 & 0.08 & 0.21 & 0.24 & 0.21 & 0.24 \\
C17:1 & 0.07 & 0.12 & 0.06 & 0.21 & 0.19 & 0.05 & 0.16 & 0.16 & 0.15 & 0.15 \\
C18:0 & 2.33 & 2.53 & 2.37 & 2.57 & 2.62 & 1.98 & 2.50 & 2.22 & 2.39 & 2.36 \\
C18:1 & 75.01 & 73.43 & 74.45 & 72.00 & 72.90 & 76.74 & 73.00 & 72.21 & 73.96 & 73.48 \\
C18:2 & 7.81 & 9.03 & 8.07 & 10.45 & 9.48 & 7.43 & 9.98 & 10.00 & 9.50 & 9.87 \\
C20:0 & 0.39 & 0.40 & 0.38 & 0.38 & 0.37 & 0.28 & 0.26 & 0.25 & 0.25 & 0.21 \\
C18:3 & 0.66 & 0.62 & 0.65 & 0.50 & 0.56 & 0.57 & 0.47 & 0.47 & 0.48 & 0.41 \\
C20:1 & 0.36 & 0.35 & 0.32 & 0.33 & 0.34 & 0.33 & 0.32 & 0.33 & 0.33 & 0.34 \\
C22:0 & 0.13 & 0.12 & 0.12 & 0.13 & 0.13 & 0.08 & 0.10 & 0.08 & 0.10 & 0.09 \\
C24:0 & 0.07 & 0.07 & 0.05 & 0.02 & 0.02 & 0.01 & 0.02 & 0.02 & 0.03 & 0.02 \\
Ratio & & & & & & & & & & \\
C18:1/C18:2 & 9.60 & 8.14 & 9.23 & 6.89 & 7.70 & 10.33 & 7.33 & 7.23 & 7.80 & 7.45 \\
\hline
\end{tabular}

${ }^{a}$ Values are means of two measurements.

However in this study, the oleic to linoleic acid ratio of oil samples, which is reported as an indication of the oxidation stability of olive oil, did not show correlation to total phenol, $o$-diphenol, OSI, and free radical scavenging activity. Only a weak correlation between PV and $\mathrm{C} 18: 1 / \mathrm{C} 18: 2$ ratio $\left(\mathrm{r}^{2}=0.571, \mathrm{P}<0.01\right)$ was found. Similar results were presented by KIRALAN and co-workers (2009).

Total phenol and $o$-diphenol contents, OSI, and free radical scavenging activities (of both non-polar and polar fractions) of oil samples are presented in Table 4 . While the sample T3 had the highest total phenol and $o$-diphenol content (151.71-12.63 mg caffeic acid $/ \mathrm{kg}$ oil, respectively), the lowest total phenol and $o$-diphenol content $(51.22-5.45 \mathrm{mg}$ caffeic acid $/ \mathrm{kg}$ oil) was detected in sample T10. o-Diphenol content level varied between 5.45 (sample T10) and 12.63 (sample T3) mg caffeic acid/kg oil.

A robust correlation was determined between the values of total phenols and $o$-diphenols $\left(\mathrm{r}^{2}=0.945, \mathrm{P}<0.01\right)$. The correlation table is not shown in the article due to table number limitations. This is not an unexpected situation since the active phenols in the virgin olive oils are mainly $o$-diphenols, such as hydroxytyrosol and its oleosidic forms, protocatechuic and caffeic acids (Papadopoulos \& Boskou, 1991; Montedoro et al., 1993; Baldioli et al., 1996). These results are in agreement with those reported by BonOLI and co-workers (2004), who found a high correlation between total phenol and $o$-diphenol $\left(\mathrm{r}^{2}=0.879, \mathrm{P}<0.0001\right)$.

RSA was measured both in methanol:water extracts and in total oil (Table 4). Sample T3, which had the highest total phenol and $o$-diphenol value, had the highest RSA value; $88.40 \%$ in methanol:water extract and $77.45 \%$ in oil. This study demonstrated that the correlation of $\mathrm{RSA}^{1}$ with $\mathrm{RSA}^{2}$ was also robust $\left(\mathrm{r}^{2}=0.885, \mathrm{P}<0.01\right)$. In fact the analysis of correlation between total phenol and $o$-diphenol value with RSA proved a strong correlation (TP and RSA ${ }^{1} \mathrm{r}^{2}=0.901$, TP and $\mathrm{RSA}^{2} \mathrm{r}^{2}=0.914$, $o$-diphenol and $\mathrm{RSA}^{1} \mathrm{r}^{2}=0.895$, $o$-diphenol and $\left.\mathrm{RSA}^{2} \mathrm{r}^{2}=0.907, \mathrm{P}<0.01\right)$. POERIO and co-workers (2008) previously observed 
Table 4. Total phenol and $o$-diphenol contents, free radical scavenging activity, and oxidation stability index of oil samples

\begin{tabular}{lccccc}
\hline Samples & $\begin{array}{c}\text { Total phenol } \\
\text { (mg caffeic acid/kg oil) }\end{array}$ & $\begin{array}{c}o \text {-Diphenol } \\
\text { (mg caffeic acid/kg oil) }\end{array}$ & RSA* $(\%)^{\text {RSA** }(\%)}$ & OSI (h) \\
\hline T1 & $121.13 \pm 0.72^{\mathrm{c} * * *}$ & $9.63 \pm 0.02^{\mathrm{d}}$ & $55.01 \pm 0.06^{\mathrm{g}}$ & $65.55 \pm 0.07^{\mathrm{c}}$ & $6.48 \pm 0.01^{\mathrm{e}}$ \\
T2 & $119.92 \pm 0.72^{\mathrm{c}}$ & $10.51 \pm 0.02^{\mathrm{c}}$ & $72.00 \pm 0.06^{\mathrm{c}}$ & $69.85 \pm 0.21^{\mathrm{b}}$ & $5.63 \pm 0.02^{\mathrm{g}}$ \\
T3 & $151.71 \pm 0.72^{\mathrm{a}}$ & $12.63 \pm 0.02^{\mathrm{a}}$ & $88.40 \pm 0.06^{\mathrm{a}}$ & $77.45 \pm 0.07^{\mathrm{a}}$ & $7.98 \pm 0.10^{\mathrm{c}}$ \\
T4 & $90.59 \pm 0.72^{\mathrm{e}}$ & $8.18 \pm 0.02^{\mathrm{g}}$ & $59.58 \pm 0.06^{\mathrm{f}}$ & $59.25 \pm 0.07^{\mathrm{f}}$ & $5.38 \pm 0.09^{\mathrm{h}}$ \\
T5 & $61.88 \pm 0.72^{\mathrm{h}}$ & $6.89 \pm 0.06^{\mathrm{h}}$ & $41.92 \pm 0.12^{\mathrm{h}}$ & $56.30 \pm 0.00^{\mathrm{h}}$ & $4.46 \pm 0.16^{\mathrm{i}}$ \\
T6 & $65.49 \pm 0.00^{\mathrm{g}}$ & $8.27 \pm 0.02^{\mathrm{fg}}$ & $38.54 \pm 0.06^{\mathrm{j}}$ & $53.90 \pm 0.14^{\mathrm{i}}$ & $5.97 \pm 0.01^{\mathrm{f}}$ \\
T7 & $100.74 \pm 0.72^{\mathrm{d}}$ & $8.52 \pm 0.08^{\mathrm{e}}$ & $59.84 \pm 0.06^{\mathrm{e}}$ & $56.75 \pm 0.07^{\mathrm{g}}$ & $7.43 \pm 0.04^{\mathrm{d}}$ \\
T8 & $124.55 \pm 0.00^{\mathrm{b}}$ & $11.58 \pm 0.02^{\mathrm{b}}$ & $78.73 \pm 0.12^{\mathrm{b}}$ & $64.95 \pm 0.07^{\mathrm{d}}$ & $9.08 \pm 0.08^{\mathrm{a}}$ \\
T9 & $79.65 \pm 0.00^{\mathrm{f}}$ & $8.31 \pm 0.06^{\mathrm{f}}$ & $61.74 \pm 0.06^{\mathrm{d}}$ & $62.70 \pm 0.28^{\mathrm{e}}$ & $8.34 \pm 0.12^{\mathrm{b}}$ \\
T10 & $51.22 \pm 0.00^{\mathrm{i}}$ & $5.45 \pm 0.11^{\mathrm{i}}$ & $40.88 \pm 0.06^{\mathrm{i}}$ & $49.70 \pm 0.00^{\mathrm{j}}$ & $4.34 \pm 0.23^{\mathrm{i}}$ \\
\hline
\end{tabular}

RSA expressed as \% reduction in concentration of DPPH after a 30 min reaction. *The free radical scavenging of methanol:water extracts; **the free radical scavenging of oils; ***values are means $\pm \mathrm{SD}$ of two measurements. Means within a column with different letters are significantly different $(\mathrm{P}<0.05)$ by one-way ANOVA analysis

a correlation between DPPH and $o$-diphenol $(0.87, \mathrm{P}<0.05)$ similar to our results. A study on the effects of compounds on the stability of virgin olive oil found out that phenolic and orthodiphenolic compounds had a share around $51 \%$, the composition of fatty acids $24 \%$, and $\alpha$-tocopherol, carotenoids, and chlorophylls in smaller percentages (APARICIO et al., 1999).

Under accelerated conditions, oxidation was very fast and hydroperoxides decomposed rapidly to secondary oxidation products. OSI ranged between $4.34 \mathrm{~h}$ (sample T10) and 9.08 h (sample T8), as shown in Table 4. It was observed that the correlation of OSI with RSA ${ }^{1}$ was higher $\left(\mathrm{r}^{2}=0.705, \mathrm{P}<0.01\right)$ than with $\mathrm{RSA}^{2}\left(\mathrm{r}^{2}=0.541, \mathrm{P}<0.05\right)$. This result can be explained by term polar paradox, which is that polar antioxidants are most effective in oils, whereas non-polar antioxidants are more effective in a polar substrate (PORTER, 1993; FRANKEL et al., 1994, 1996).

A weak positive correlation was observed between OSI and total phenol value $\left(r^{2}=0.619\right.$, $\mathrm{P}<0.01)$. A comparable result $(\mathrm{r}=0.56, \mathrm{P}<0.05)$ was found in a similar study (CERRETANI et al., 2005). Moreover, it is known that under the Rancimat conditions $o$-diphenols rapidly became depleted from the outset (MAnceBo-CAmpos et al., 2007). Therefore, although these rapid assays are very useful in measuring the relative oxidative stability index for virgin olive oils and other edible oils, they cannot be used to predict the real shelf-life of these food products. There is an unsatisfactory correlation between stability at $25^{\circ} \mathrm{C}$ and stability under rancimat conditions $\left(\mathrm{r}^{2}=0.55, \mathrm{P}<0.01\right)$. A probable reason for that are the different oxidation mechanisms at $25^{\circ} \mathrm{C}$ and temperatures higher than $60{ }^{\circ} \mathrm{C}$ (Mancebo-CAmpos et al., 2007).

Schaal oven test was performed at $60^{\circ} \mathrm{C}$. Peroxide, conjugated diene and triene values of the oils were monitored for 30 days and plotted against time, as indicated in Figs 1 and 2, respectively.

Peroxides, especially hydroperoxides, are primary oxidation products during iniation step of lipid oxidation. Differences among samples emerged after the fifteenth day of 30 days storage at $60{ }^{\circ} \mathrm{C}$. At the end of the 30 days storage T5, T10, and T6 samples reached the 
highest PV values $\left(272.98,251.53\right.$, and $216.61 \mathrm{meq} \mathrm{O}_{2} / \mathrm{kg}$ oil, respectively), peroxide formation in $\mathrm{T} 3$ ( $\mathrm{PV}=66.08 \mathrm{meq}_{2} / \mathrm{kg}$ oil) occurred to be less than in other samples (Fig. 1).

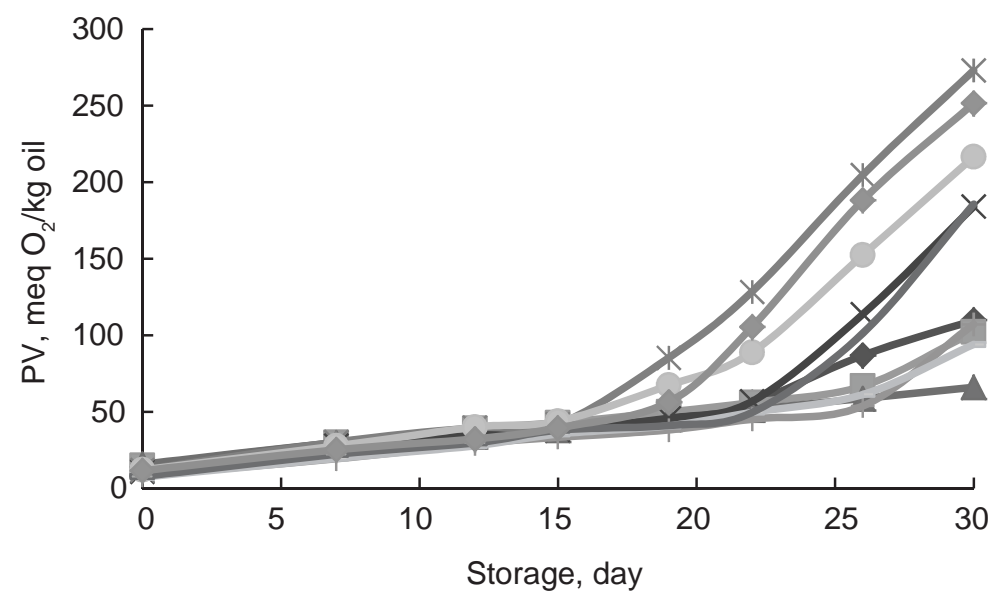

Fig. 1. Changes in $\mathrm{PV}$ (meq $\mathrm{O}_{2} / \mathrm{kg}$ oil) of oil samples during storage at $60^{\circ} \mathrm{C}$.

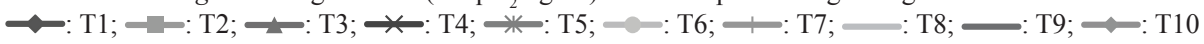

During the oxidation process, free lipid radicals formed and two conjugated double bonds derived from the original pentadienoic double bond systems. UV absorption is a suitable method to monitor the changes in lipid oxidation (KAMAL-ELDIN \& POKORNY, 2005). As shown in Fig. 2, after the fifteenth day of storage there is a significant increase in the amount of free lipid radicals as PV values, especially in sample T5. Sample T5 reached 27.64 at the end of 30 day storage, followed by sample T10 with 20.44. On the other hand, diene values of T3 and T8 samples were 11.54 and 11.75, respectively, at the end of the storage period, which were lower than values of the other samples.

Triene value is correlated to the presence of secondary oxidation products. The results obtained for the triene value are presented in Fig. 2. During the storage, a significant increase of this value occurred in all experiments. The highest value (1.52) was observed in T5, the lowest value $(0.52)$ was recorded in $\mathrm{T} 8$ at the end of the storage.

\section{Conclusion}

This study shows that there is a consistency between $\mathrm{PV}, \mathrm{K}_{232}$, and $\mathrm{K}_{270}$ values of the samples stored at $60{ }^{\circ} \mathrm{C}$. According to Schaal oven test results sample T3, which had highest TP and $o$-diphenol content and RSA value, is the most resistant to oxidation. T5 and T10 samples, which have lowest TP and $o$-diphenol levels and OSI and RSA values, proved to be most vulnerable to oxidation. Results proved that TPC, especially the $o$-diphenol content of the oil, is the most important characteristic of the extra virgin olive oil in order to determine oxidation. The C18:1/C18:2 ratio and the initial PV appeared to have no important effect on the oxidation stability during the storage period. 

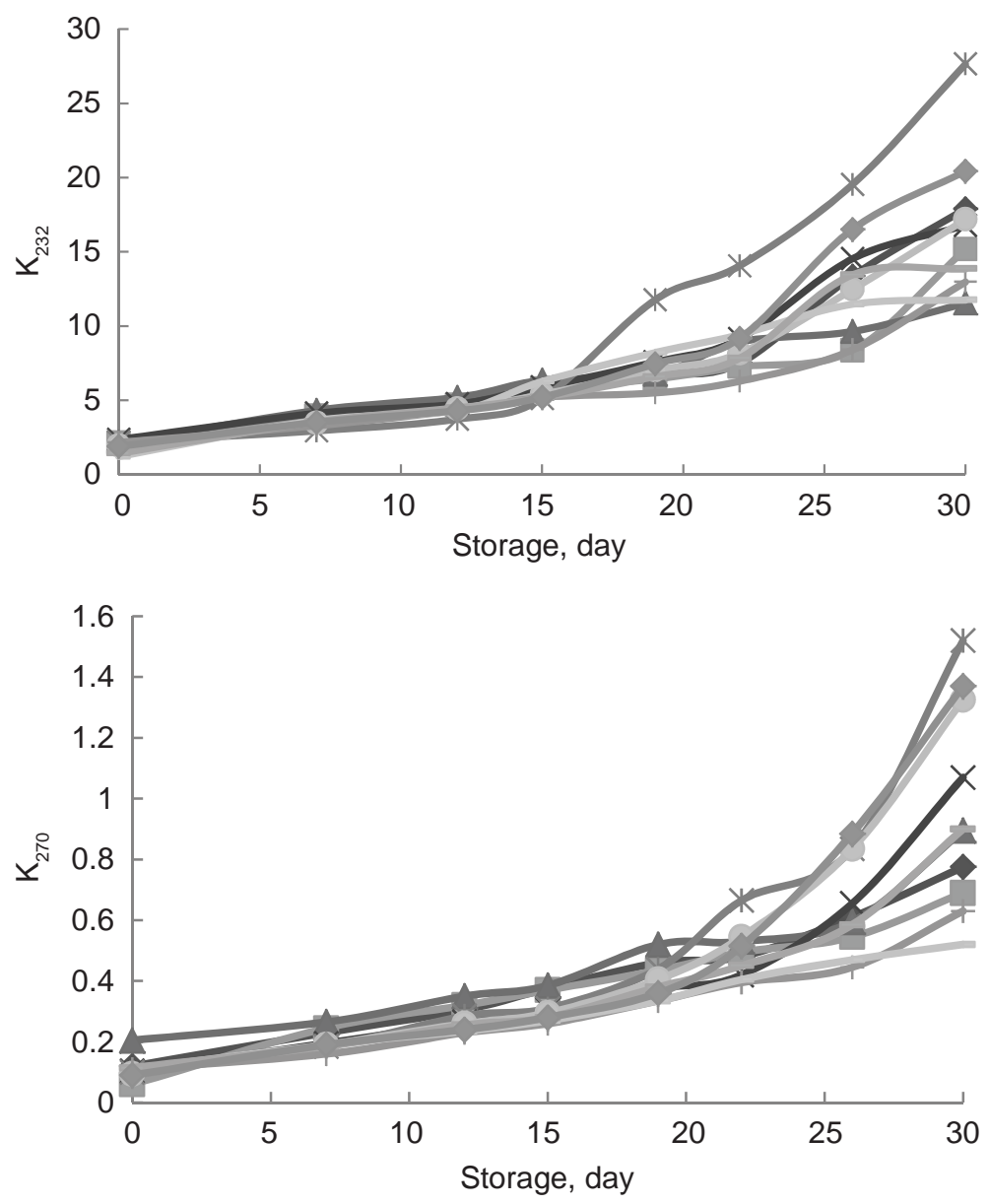

Fig. 2. Changes in K232 and K270 values of oil samples during storage at $60{ }^{\circ} \mathrm{C}$.

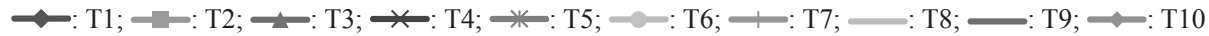

\section{References}

ANON. (2006): COI/T.15/NC no. 3/Rev. 2. 24 November 2006. Trade Standard applying to olive oils and olivepomace oils.

ANON. (2008): OLEA databases. http://www.oleadb.it Accessed November 2008.

ANON. (2009): International Olive Oil Council. World olive oil figures. http://www.internationaloliveoil.org. Accessed November 2009.

A.O.C.S. (1997a): Peroxide value, acetic acid-chloroform method. -in: Official methods and recommended practices of the American Oil Chemists Society. Official method, Cd 8-53.

A.O.C.S. (1997b): Free fatty acids. -in: Official methods and recommended practices of the American Oil Chemists Society. Official method, Ca $5 a-40$.

A.O.C.S. (2005): Determination of specific extinction of oils and fats, Ultraviolet absorption. -in: Official methods and recommended practices of the American Oil Chemists Society. Official method, Ch 5-91.

Aparicio, R., Morales, M.T.\&Alonso, V. (1997): Authentication of European virgin olive oils by their chemical compounds, sensory attributes and consumers' attitudes. J. Agric. Fd Chem., 45, 1076-1083. 
Aparicio, R., Roda, L., Albi, M.A. \& Gutiérrez, F. (1999): Effect of various compounds on virgin olive oil stability measured by Rancimat. J. Agric. Fd Chem., 47, 4150-4155.

Baldioli, M., Servili, M., Perretti, G. \& Montedoro, G. (1996): Antioxidant activity of tocopherols and phenolic compounds in virgin olive oil. J. Am. Oil Chem. Soc., 73, 1589-1593.

Beltrán, G., Aguilera, P.M., Del Rio, C., Sanchez, S. \& Martinez, L. (2005): Influence of fruit ripening process on the natural antioxidant content of Hojiblanca virgin olive oils. Fd Chem., 89, 207-215.

Bonoli, M., Bendini, A., Cerretani, L., Lercker, G. \& Toschi, T.G. (2004): Qualitative and semiquantitative analysis of phenolic compounds in extra virgin olive oils as a function of the ripening degree of olive fruits by different analytical techniques. J. Agric. Fd Chem., 52, 7026-7032.

Cerretani, L., Bendini, A., Rotondi, A., Lercker, G. \& Toschi, T.G. (2005): Analytical comparison of monovarietal virgin olive oils obtained by both a continuous industrial plant and a low-scale mill. Europ. J. Lipid Sci. Technol., 107, 93-100.

Frankel, E.N., Huang, S.W., Kanner, J.\&German, J.B. (1994): Interfacial phenomena in the evaluation of antioxidants in bulk oils versus emulsions. J. Agric. Fd Chem., 42, 1054-1059.

Frankel, E.N., Huang, S-W., Aeschbach, R.\& Prior, E. (1996): Antioxidant activity of rosemary extract and its constituents, carnosic acid, carnosol, and rosmarinic acid, in bulk oil and oil-in-water emulsion. J. Agric. Fd Chem., 44, 131-135.

IUPAC (1987): Standard methods for analysis of oils, fats and derivatives. Blackwell Scientific Publications, $7^{\text {th }}$ ed., IUPAC Method 2.301, Report of IUPAC Working group WG 2/87.

Kalantzakis, G., Blekas, G., Pegklidou, K. \& Boskou, D. (2006): Stability and radical scavenging activity of heated olive oil and other vegetable oils. Europ. J. Lipid Sci. Technol., 108, 329-335.

Kamal-Eldin, A.\& Pokorny, J. (2005): Analysis of lipid oxidation. AOCS Press, USA, 293 pages.

Kiralan, M., Bayrak, A.\& Ozkaya, M.T. (2009): Oxidation stability of virgin olive oils from some important cultivars in East Mediterranean area in Turkey. J. Am. Oil Chem. Soc., 86, 247-252.

Kiritsakis, A.K. (1998): Olive oil: From the tree to the table. $2^{\text {nd }}$ ed., Food \& Nutrition Press, Trumbull, CT, p. 348.

Koprivnjak, O., Škevin, D., Valic, S., Majetic, V., Petricevic, S. \& Ljubenkov, I. (2008): The antioxidant capacity and oxidative stability of virgin olive oil enriched with phospholipids. Fd Chem., 111, 121-126.

Mancebo-Campos, V., Salvador, M.D.\& Fregapane, G. (2007): Comparative study of virgin olive oil behavior under Rancimat accelerated oxidation conditions and long-term room temperature storage. J. Agric. Fd Chem., $55,8231-8236$.

Montedoro, G., Servili, M., Baldioli, M., Selvaggini, R., Miniati, E.\& Maccioni, A. (1993): Simple and hydrolyzable phenolic compounds in virgin olive oil: Note 3. Spectroscopic characterization of the secoroidoid derivatives. J. Agric. Fd Chem., 41, 2228-2234.

Papadopoulos, G. \& Boskou, D. (1991): Antioxidant effect of natural phenols on olive oil. J. Am. Oil Chem. Soc., 68, $669-671$.

Poerio, A., Bendini, A., Cerretani, L., Bonoli-Carbognin, M. \& Lercker, G. (2008): Effect of olive fruit freezing on oxidative stability of virgin olive oil. Europ. J. Lipid Sci. Technol., 110, 368-372.

Porter, W.L. (1993): Paradoxical behaviour of antioxidants in food and biological systems. Toxicol. Ind. Health, 9 , 93-122.

Velasco, J.\& Dobarganes, C. (2002): Oxidative stability of virgin olive oil. Europ. J. Lipid Sci. Technol., 104, $661-676$.

WAGNER, K-H. \& ElmADFA, I. (2000): Effects of tocopherols and their mixtures on the oxidative stability of olive oil and linseed oil under heating. Europ. J. Lipid Sci. Technol., 102, 624-629. 